\title{
Effects of nutrient enrichment on growth and phlorotannin production in Fucus gardneri embryos
}

\author{
Kathryn L. Van Alstyne*, Karen N. Pelletreau \\ Shannon Point Marine Center, 1900 Shannon Point Road, Anacortes, Washington 98221, USA
}

\begin{abstract}
Resource-allocation models predict trade-offs between growth and chemical defense. The carbon/nutrient balance hypothesis $(\mathrm{CNBH})$ predicts that plants will allocate carbon to growth when nutrients are abundant and allocate it to carbon-based antiherbivore defenses when nutrients are limiting. In marine systems, field and laboratory tests of the CNBH with phlorotannin-producing algae have generally supported the predictions of the model. However, these tests have all measured phlorotannin concentrations in adult algae rather than juveniles, which are susceptible to higher grazing pressures. We experimentally tested some of the predictions of the CNBH in early post-settlement stages of a common intertidal macroalga, Fucus gardneri, by growing F. gardneri embryos in media enriched with 3 nutrients: nitrogen, phosphorus, and iron. Phlorotannin concentrations across all treatments were correlated with embryo size but not with growth rates. As predicted by the model, nitrogen enrichment significantly enhanced embryo growth rates and decreased phlorotannin concentrations. Iron enrichment alone had no effect on phlorotannin concentrations, but did affect growth. The effects on growth were primarily in altering morphology rather than changing the overall size of the embryos. Phosphorus enrichment had no effect on growth, but did significantly lower phlorotannin concentrations. Surprisingly, there was a significant iron-phosphorus interaction effect on both growth and phlorotannin concentrations. Enrichment with a combination of iron and phosphorus had a stronger negative effect on growth and phlorotannin concentrations than would have been predicted based on the individual effects of these 2 nutrients. The combination of iron and phosphorus enrichment may have physiologically stressed the embryos, resulting in decreased phlorotannin production. Our results suggest that ontogeny plays a strong role in determining secondary metabolite levels and that nutrient addition can affect secondary metabolite production in embryos by (1) altering resource allocation patterns, or (2) providing a physiological stress that results in reduced secondary metabolite production.
\end{abstract}

KEY WORDS: Phlorotannins $\cdot$ Nutrients $\cdot$ Chemical defense $\cdot$ Resource allocation $\cdot$ Fucus

\section{INTRODUCTION}

Nutrients, such as nitrogen, phosphorus, and iron are thought to limit the growth of algae in many marine systems. A recent meta-analysis of the effects of nutrient addition on phytoplankton has emphasized that there is no one limiting nutrient in the oceans (Downing et al. 1999). Instead, the ability of enhanced concentrations of a nutrient to increase phytoplankton

*E-mail: kathyva@cc.wwu.edu growth will depend on location. For example, nitrogen enhances algal growth in all but pristine waters. In pristine oceanic waters, iron and phosphorus tend to be limiting (Martin \& Fitzwater 1988, Martin et al. 1994, Coale et al. 1996, Downing et al. 1999). Phosphorus limitation also tends to be more important in low latitude environments (Short et al. 1985). The ability of nutrients to limit the growth of macroalgae is not as well understood. Nitrogen is considered the major nutrient limiting growth of many coastal macroalgal species during at least some portions of the year (Fujita 
et al. 1989, Wheeler \& Björnsäter 1992, Pedersen \& Borum 1996, 1997, Stimson et al. 1996, Larned 1998, but see Wootton et al. 1996, Nielsen 1998). However, both phosphorus and iron also have the potential to limit macrophyte growth (Delgado \& LaPointe 1994, LaPointe 1995, 1997, Suzuki et al. 1995).

Nutrients may also affect other aspects of resource allocation in plants. Plants have limited resources to partition among essential functions, including growth, reproduction, and defense (Bazzaz et al. 1987). The carbon/nutrient balance hypothesis $(\mathrm{CNBH})$ predicts that nutrient concentrations regulate resource allocation to growth and defense in plants (Bryant et al. 1983). Plants that are not light- or carbon-limited are predicted to allocate carbon to growth when nutrients are abundant and to carbon-based defensive compounds when nutrients are limiting.

In marine systems, tests of the $\mathrm{CNBH}$ hypothesis with phlorotannin-producing algae have generally supported the predictions of the model. Phlorotannins have concentration-dependent (Geiselman \& McConnell 1981, Steinberg 1985) antifeeding activity towards many (Ragan \& Glombitza 1986, Steinberg 1988, Steinberg \& van Altena 1992, Winter \& Estes 1992, Steinberg et al. 1995, Targett \& Arnold 1998), although not all, herbivores. Phlorotannin concentrations in populations of Fucus vesiculosus from 3 sites from the northern Baltic Sea were negatively correlated with the nitrogen concentration of algal thalli (Ilvessalo \& Tuomi 1989). Similar patterns were found in populations of F. vesiculosus in estuarine sites in Massachusetts, USA (Yates \& Peckol 1993). Algae at a low-nitrogen site generally had higher phlorotannin concentrations than algae at a high-nitrogen site, although some seasonal variation in phlorotannin concentrations did occur. Yates \& Peckol conducted experimental enrichments with an ammonium nitrate and phosphate fertilizer at both sites. Enrichment resulted in an increase in tissue nitrogen concentrations in algae from both sites but a decrease in phlorotannin concentrations only in algae from the low-nitrogen site. At both sites, growth rates were higher in fertilized algae, but the response was more pronounced in the low-nitrogen site. Pavia et al. (1999) found growth rates and phlorotannin concentrations to be negatively correlated in Northern Atlantic Ascophyllum nodosum, but both growth and phlorotannin concentrations were generally unrelated to tissue nitrogen concentrations or highly variable.

In laboratory-culture experiments, the tropical brown alga Lobophora variegata fertilized with different concentrations of nitrogen showed patterns that were consistent with the CNBH. Algae grown in high-nitrogen media had higher nitrogen concentrations and lower phlorotannin concentrations than algae grown in lownitrogen media (Arnold et al. 1995). However, results of similar experiments that measured terpene production in tropical algae under different nutrient regimes have produced contrasting results. Puglisi \& Paul (1997) conducted field experiments in which they added nitrogen, phosphorus, and a combined nitrogen/phosphorus treatment to sites containing the tropical red alga Portieria hornemannii. They found no differences in concentrations of the terpene octodene or in triglyceride concentrations in any of their experimental treatments. Similarly, terpene concentrations in the brown alga Dictyota ciliolata did not change when the algae were fertilized with ammonium chloride and with plant food containing nitrogen, phosphorus and potassium (Cronin \& Hay 1996a).

Previous tests of the CNBH with seaweeds have primarily been conducted on adults. However, grazing pressures on many seaweeds are thought to be most intense during juvenile stages (see reviews by Hawkins \& Hartnoll 1983, Chapman 1986, Santelices 1990, and Vadas et al. 1992). In intertidal algae, high rates of mortality occur in early post-settlement periods and herbivory can be the major factor limiting survival through juvenile stages (e.g., Hawkins 1981, 1983, Lubchenco 1983, Harris et al. 1984, Keser \& Larson 1984, Gunnill 1986, Dean et al. 1988, Chapman 1990).

The impact of herbivores changes as algae pass through different life history stages. For example, field experiments showed that the major cause of mortality in Lessionia nigrescans gametophytes <15 $\mu \mathrm{m}$ long was herbivory, but in larger sporophytes the primary source of mortality was wave action (Martinez \& Santelices 1998). The palatability of algae also changes as the plants get larger. In laboratory feeding experiments, littorinid snails preferred 1 to $3 \mathrm{~cm}$ juvenile Fucus serratus to individuals that were 5 to $7 \mathrm{~cm}$ long (Lubchenco 1983). Juvenile Ulva lactuca were preferred to adult U. lactuca by Littorina littorea, but adult Fucus serratus were preferred to juveniles (Watson \& Norton 1987). Van Alstyne et al. (1999a) found that intertidal urchins, snails, and isopods often had distinct preferences when offered tissues from juvenile and adult kelps and rockweeds, but the preferences were not predictable; herbivores could prefer adult tissues, juvenile tissues, or exhibit no preference, depending on the algal species and herbivore species being examined.

The high mortality rates of juveniles and the shifts in herbivore preferences among life history stages suggest 2 mutually exclusive resource-allocation strategies that juveniles may have evolved for surviving herbivory: (1) juveniles may allocate more resources for defense at a cost of lower growth rates, or (2) they may allocate fewer resources to defense and grow rapidly in order to 'escape in size'. Both strategies assume that defense production incurs metabolic costs, an assump- 
tion that has not been rigorously tested in most systems (Angrawal \& Karban 1999).

Concentrations of defensive compounds in juveniles and adults provide evidence that both strategies may be used. Small juveniles of the brown algae Alaria marginata, Egregia menziesii, Fucus gardneri, Hedophyllum sessile, and Lessoniopsis littoralis produced higher concentrations of phlorotannins than older or adult stages (Van Alstyne et al. 2001b). Juveniles of the siphonous green algae Halimeda macroloba were significantly less calcified and contained higher concentrations of the diterpenoid feeding-deterrent halimedatrial than adult tissues (Paul \& Van Alstyne 1988). Lipid-soluble extracts from juveniles were more deterrent towards herbivorous fishes than were extracts from adults (Paul \& Van Alstyne 1988). However, in other species, defense levels may be lower in juveniles than adults. Juveniles of the rockweeds $F$. vesiculosus and F. evenescens (Denton et al. 1990) and the kelp Nereocystis luetkeana (Van Alstyne et al. 2001b) had lower concentrations of phlorotannins than adults.

The CNBH suggests that resource allocation towards chemical defenses is dynamic and shifts with changes in concentrations of limiting nutrients (Bryant et al. 1983). Juvenile marine macroalgae are a useful system to test the predictions of the $\mathrm{CNBH}$ because juveniles have conflicting pressures to grow rapidly to escape in size from herbivores and to produce chemical defenses that deter herbivores. The purpose of this study was to determine experimentally how nutrient enrichment affected growth rates and phlorotannin concentrations in early post-settlement stages of a common intertidal macroalga, Fucus gardneri. Fucoid brown algae or rockweeds have a haplobiontic life history (Bold \& Wynne 1985). F. gardneri is dioecious and releases eggs and motile sperm into seawater where fertilization occurs. In some Fucus species, gamete release is triggered by a combination of dissolved inorganic carbon depletion during periods of low water movement and daylight (Pearson et al. 1998). Fertilization occurs within a few hours (Pearson et al. 1998) and propagules settle within a short distance of adults (Johnson \& Brawley 1998). Zygotes develop directly into diploid adults.

The CNBH predicts that enrichment with nitrogen, which can be the limiting nutrient to some coastal marine macroalgae (Fujita et al. 1989, Wheeler \& Björnsäter 1992, Pedersen \& Borum 1996, 1997), will cause increased growth rates and decreased phlorotannin concentrations of Fucus gardneri embryos. Nonlimiting nutrients should not affect growth or phlorotannin concentrations. To test these hypotheses with F. gardneri embryos, we grew embryos in media with ambient and enhanced concentrations of nitrogen, phosphorus, and iron and measured the effects of nutrient enrichment on embryo growth rates and phlorotannin concentrations.

\section{MATERIALS AND METHODS}

Fertile receptacles from at least 25 Fucus gardneri were collected from the beach at the Shannon Point Marine Center, Anacortes, Washington, USA. The receptacles were cleaned of visible epiphytes and placed overnight in $5 \mu \mathrm{m}$-filtered seawater at $8^{\circ} \mathrm{C}$. The next morning, the receptacles were removed and the eggs were collected on a $40 \mu \mathrm{m}$ filter, rinsed 3 times with filtered seawater, then added to 41 of sterile $5 \mu \mathrm{m}$ filtered seawater. The suspension was shaken and $50 \mathrm{ml}$ was distributed into each of $72100 \mathrm{ml}$ glass fingerbowls. Fertilized eggs were allowed to settle and attach for $6 \mathrm{~d}$ before nutrient-enriched media was added to the cultures. The bowls were randomly arranged on 2 shelves of an incubator $\left(12^{\circ} \mathrm{C}, 43 \mu \mathrm{E} \mathrm{m} \mathrm{m}^{-2} \mathrm{~s}^{-1}, 16: 8 \mathrm{~h}\right.$ L:D) and the media was changed weekly and the dishes rotated.

A total of 8 different types of media were distributed among the 72 bowls ( $\mathrm{n}=9$ of for each treatment): (1) a base medium, that consisted of sterile Guillard's f/2 enriched seawater medium (McLachlan1973) except that it lacked $\mathrm{NaNO}_{3}, \mathrm{NaH}_{2} \mathrm{PO}_{4} \cdot \mathrm{H}_{2} \mathrm{O}$, and $\mathrm{FeCl}_{3} \cdot 6 \mathrm{H}_{2} \mathrm{O}$; (2) an enriched nitrogen medium, that consisted of the base medium plus $75.0 \mathrm{mg} \mathrm{l}^{-1} \mathrm{NaNO}_{3}$ (3) an enriched phosphorus medium that consisted of the base medium plus $5.0 \mathrm{mg} \mathrm{l}^{-1} \mathrm{NaH}_{2} \mathrm{PO}_{4} \cdot \mathrm{H}_{2} \mathrm{O}_{\text {; }}$ (4) an enriched iron medium, that consisted of the base medium plus

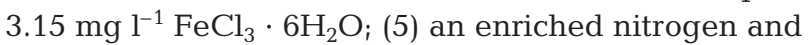
phosphorus medium that consisted of the base medium plus $75.0 \mathrm{mg} \mathrm{l}^{-1} \mathrm{NaNO}_{3}$ and $5.0 \mathrm{mg} \mathrm{l}^{-1} \mathrm{NaH}_{2} \mathrm{PO}_{4} \cdot \mathrm{H}_{2} \mathrm{O}$; (6) an enriched nitrogen and iron medium that consisted of the base medium plus $75.0 \mathrm{mg} \mathrm{l}^{-1} \mathrm{NaNO}_{3}$ and

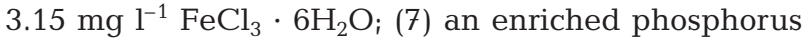
and iron medium that consisted of the base medium plus $5.0 \mathrm{mg} \mathrm{l}^{-1} \mathrm{NaH}_{2} \mathrm{PO}_{4} \cdot \mathrm{H}_{2} \mathrm{O}$ and $3.15 \mathrm{mg} \mathrm{l}^{-1} \mathrm{FeCl}_{3} \cdot 6 \mathrm{H}_{2} \mathrm{O}$; (8) an enriched nitrogen, phosphorus and iron medium that consisted of the base medium plus $75.0 \mathrm{mg} \mathrm{l}^{-1}$ $\mathrm{NaNO}_{3}, 5.0 \mathrm{mg} \mathrm{l}{ }^{-1} \mathrm{NaH}_{2} \mathrm{PO}_{4} \cdot \mathrm{H}_{2} \mathrm{O}$, and $3.15 \mathrm{mg} \mathrm{l}^{-1}$ $\mathrm{FeCl}_{3} \cdot 6 \mathrm{H}_{2} \mathrm{O}$. All media were made with seawater collected $50 \mathrm{~m}$ off the beach at the Shannon Point Marine Center at a depth of $5 \mathrm{~m}$.

Embryos in 3 bowls from each of the 8 treatments were harvested 27 and $48 \mathrm{~d}$ after the cultures were started; 2 collections of embryos from each bowl were made. The first consisted of a small number of embryos that were carefully scraped off the bottoms of the bowls and fixed in $10 \%$ glutaraldehyde for later morphometric measurements; the second consisted of the remaining embryos, which were scraped from the bowl and filtered onto $13 \mathrm{~mm}$-diameter glass-fiber filters 
that had been lyophilized, weighed, and stored in a desiccator to prevent hydration. The filters with the embryos were frozen to $-50^{\circ} \mathrm{C}$, lyophilized, and weighed to the nearest $0.001 \mathrm{mg}$. They were ground in a glass tissue-homogenizer in $0.5 \mathrm{ml} 80 \% \mathrm{MeOH}$, then centrifuged at $14000 \mathrm{rpm}$. The supernatant was used to determine phlorotannin concentrations as described in Van Alstyne (1995). Phloroglucinol dihydrate was used as a standard. The data were transformed with an angular transformation and a 4-way analysis of variance was used to examine the effects of the fixed factors (1) nitrogen addition, (2) phosphorus addition, (3) iron addition, and (4) sampling time on phlorotannin concentrations.

Samples fixed in $10 \%$ gluteraldehyde were used for morphometric analyses. From each sample, measurements were conducted on approximately 25 embryos that were haphazardly selected. Only embryos with intact rhizoids were used for the analyses. Measurements were made at $40 \times$ using an image-analysis system with Optimas 6.2 software. They included the length of the embryo from the base of the rhizoid to the distal end, the maximum width of the pigmented portion of the embryo, the length of the rhizoid from its base to the distal end of the rhizoid, and the surface area of the pigmented portion of the embryo.

Principal-components analyses indicated that embryo length, rhizoid length, and photosynthetic surface area cumulatively explained $96.1 \%$ of the variance in the morphometric measurements. Therefore, only these 3 measurements were used in the factorial MANOVA (multivariate analyses of variance) to examine the effects of nutrient enrichment. Approximately $60 \%$ of the variance was explained by amount of photosynthetic surface area, $21 \%$ was explained by em- bryo length, $15 \%$ was explained by rhizoid length, and only $4 \%$ was explained by the width of the embryos. MANOVA was performed on the data to examine the effects of enrichment with nitrogen, phosphorus, and iron, and the effects of the time at which measurements were made.

\section{RESULTS}

The addition of nitrogen and iron to culture media significantly affected the growth of Fucus gardneri embryos (nitrogen: $p=0.0357$, iron: $p=0.0168$, Table 1). After $3 \mathrm{wk}$ in culture, embryos growing in nitrogen-enhanced media were longer, wider, and had a greater surface area (Fig. 1). This trend continued in the embryos at the 6 wk measurements (Fig. 1, Table 2). The addition of iron to the media tended to affect the shape of the embryos rather than resulting in overall increases in size (Fig. 1, Table 2). After $6 \mathrm{wk}$, embryos grown in media enriched with iron alone were, on average, shorter and wider than embryos grown in media without iron (Table 2). They also had a slightly larger photosynthetic surface area but shorter rhizoids.

Although the addition of phosphorus alone had no significant effects on embryo size $(p=0.5641$ : Table 1$)$, there was a significant phosphorus $\times$ iron interaction effect ( $p=0.0307$ : Table 1$)$. In the absence of phosphorus enrichment, the addition of iron resulted in embryos that were, on average, $17.0 \%$ longer and that had $22.5 \%$ longer rhizoids after $3 \mathrm{wk}_{\text {; }}$ after $6 \mathrm{wk}$, iron enrichment resulted in embryos that were $7.8 \%$ longer, $14.4 \%$ wider, with $23.2 \%$ more surface area and rhizoids that were $36.7 \%$ shorter than embryos in

Table 1. Fucus gardneri. Results of multivariate analysis of variance of embryo lengths, rhizoid lengths, and photosynthetic surface area of embryos grown in 8 different media enriched with nitrogen, phosphorus, and iron. Measurements were made 27 and $48 \mathrm{~d}$ after cultures were started. Bold indicates treatments that had significant effects on growth

\begin{tabular}{|c|c|c|c|c|c|}
\hline Source & Wilks' lambda & $F$ & Numerator df & Denominator df & $\mathrm{p}$ \\
\hline $\mathbf{N}$ & 0.73219256 & 3.2918 & 3 & 27 & 0.0357 \\
\hline $\mathrm{P}$ & 0.92846073 & 0.6935 & 3 & 27 & 0.5641 \\
\hline $\mathbf{F e}$ & 0.68938189 & 4.0552 & 3 & 27 & 0.0168 \\
\hline Time & 0.57681987 & 6.6028 & 3 & 37 & 0.0017 \\
\hline $\mathrm{N} \times \mathrm{P}$ & 0.94654272 & 0.5083 & 3 & 27 & 0.6799 \\
\hline $\mathrm{N} \times \mathrm{Fe}$ & 0.84495861 & 1.6514 & 3 & 27 & 0.2009 \\
\hline $\mathrm{N} \times$ Time & 0.92209413 & 0.7604 & 3 & 27 & 0.5261 \\
\hline $\mathbf{P} \times \mathbf{F e}$ & 0.72333817 & 3.4423 & 3 & 27 & 0.0307 \\
\hline $\mathrm{P} \times$ Time & 0.92758395 & 0.7026 & 3 & 27 & 0.5587 \\
\hline Fe $\times$ Time & 0.89360211 & 1.0716 & 3 & 27 & 0.3776 \\
\hline $\mathrm{N} \times \mathrm{P} \times \mathrm{Fe}$ & 0.92253290 & 0.7557 & 3 & 27 & 0.5287 \\
\hline $\mathrm{N} \times \mathrm{P} \times$ Time & 0.97306952 & 0.2491 & 3 & 27 & 0.8613 \\
\hline $\mathrm{N} \times \mathrm{Fe} \times$ Time & 0.98586913 & 0.1290 & 3 & 27 & 0.9420 \\
\hline $\mathrm{P} \times \mathrm{Fe} \times$ Time & 0.94839441 & 0.4897 & 3 & 27 & 0.6923 \\
\hline $\mathrm{N} \times \mathrm{P} \times \mathrm{Fe} \times$ Time & 0.83664772 & 1.7572 & 3 & 27 & 0.1719 \\
\hline
\end{tabular}



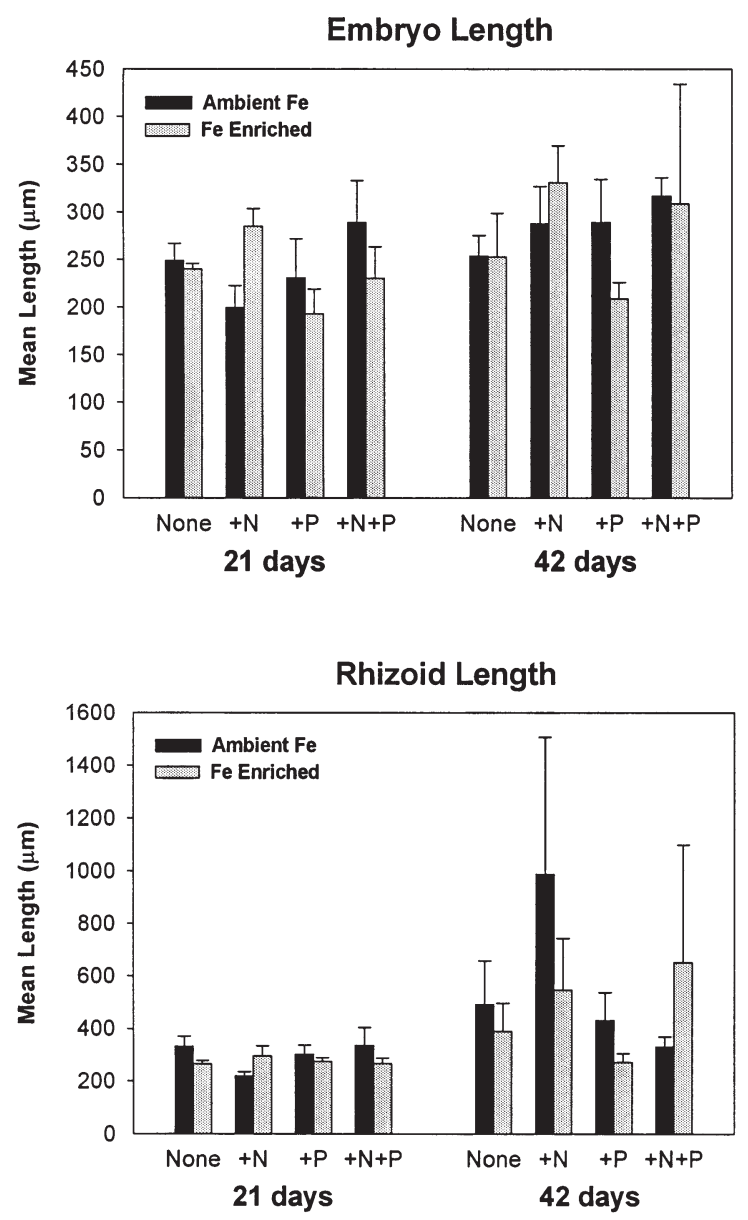

Fig. 1. Fucus gardneri. Lengths, widths, rhizoid lengths, photosynthetic surface areas and phlorotannin concentrations of cultured embryos. Values are means +1 SE from 2 to 3 cultures; days are number of days embryos were grown in culture media. Results from MANOVA of morphometric data are in Table 1 and results from ANOVA of phlorotannin data are given in Table 3

unenriched media (Fig. 1). However, when the media were enriched with both phosphorus and iron, 3 wkold embryos were $20.0 \%$ shorter, had $14.6 \%$ less surface area, and $14.6 \%$ shorter rhizoids (Fig. 1) than embryos in media without iron enrichment. Six wk-old embryos in the iron and phosphorus enriched media were $18.6 \%$ shorter, $7.2 \%$ wider, had rhizoids that
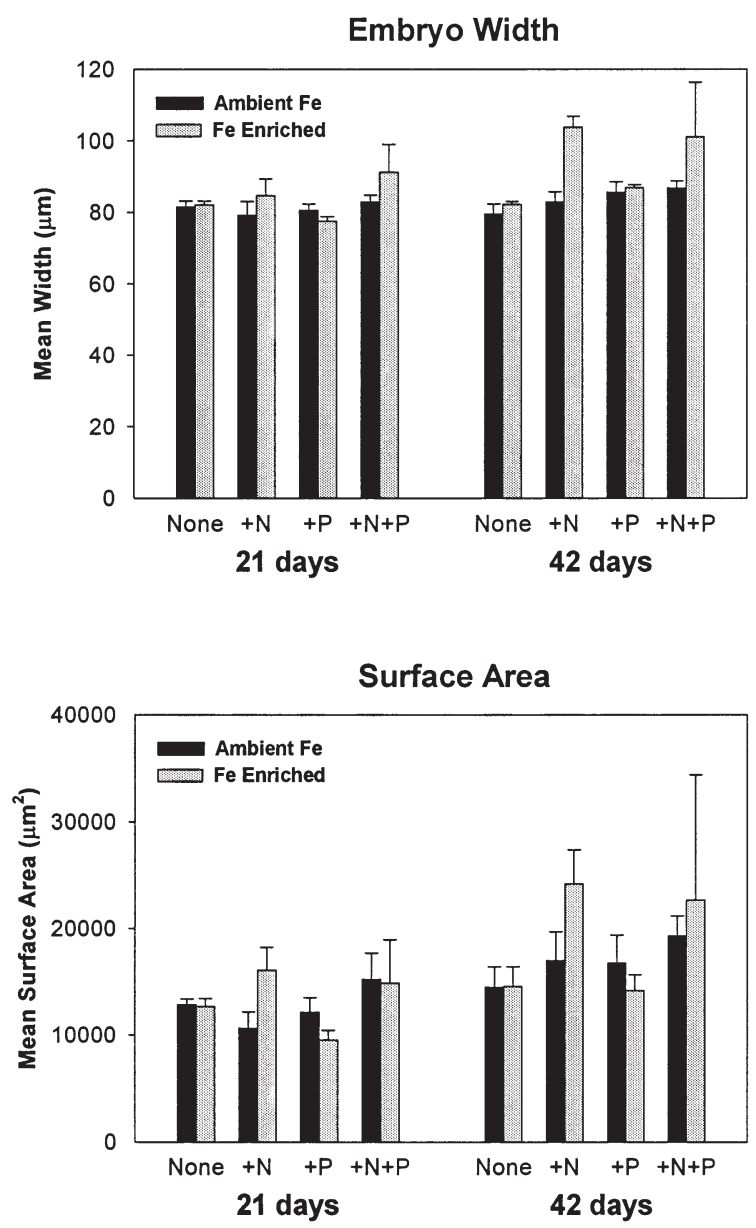

Phlorotannin Concentration

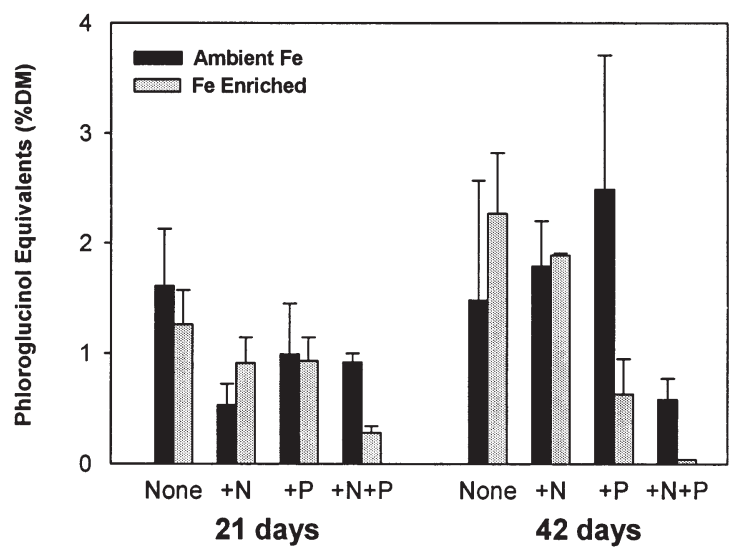

were $14.5 \%$ longer, and had $4 \%$ less surface area (Fig. 1).

Phlorotannin concentrations of embryos were significantly lower when embryos were grown in media enriched with nitrogen $(\mathrm{p}=0.013)$ or phosphorus $(\mathrm{p}=$ 0.004, Fig. 1, Tables 2 \& 3). Enrichment with iron alone had no significant effect on phlorotannin concentra- 
tions (Table 3: $\mathrm{p}=0.189$ ), however, phosphorus $\times$ iron had a significant synergistic effect on phlorotannin concentrations $(p=0.009)$. In the absence of phosphorus enrichment, iron enrichment resulted in 2.0 and $27.2 \%$ increases in phlorotannin concentrations over 3 and $6 \mathrm{wk}$, respectively (Fig. 1). However, when media was enriched with phosphorus, the addition of iron resulted in 36.6 and $64.3 \%$ decreases in mean phlorotannin concentrations over 3 and $6 \mathrm{wk}$, respectively (Fig. 1).

Phlorotannin concentrations of embryos across all experiments were not significantly correlated with changes in embryo length, width, or surface area (Fig. 2, linear regressions: $\mathrm{p}>0.05$ ); however, there was a positive correlation between phlorotannin concentration and the increase in rhizoid length (Fig. 2: linear regression: $r^{2}=15.1 \%, p=0.005$ ). Phlorotannin concentrations were significantly and positively corre- lated with length (linear regression: $\mathrm{r}^{2}=20.4 \%, \mathrm{p}=$ 0.001 ), rhizoid length (linear regression: $\mathrm{r}^{2}=24.9 \%, \mathrm{p}<$ 0.001 ), and surface area (linear regression: $\mathrm{r}^{2}=11.3 \%$, $p=0.015$ ) of the embryos (Fig. 3), suggesting that size was a more important determinant of phlorotannin levels than growth rates.

\section{DISCUSSION}

Phlorotannin concentrations in the Fucus gardneri embryos in our experiments tended to be positively correlated with measurements of embryo size (Fig. 2) rather than growth rates (Fig. 3). This suggests that in F. gardneri embryos, ontogenetic changes are more important determinants of phlorotannin levels than are trade-offs in the allocation of resources to growth and secondary metabolite production.

Table 2. Fucus gardneri. Changes in size and phlorotannin concentrations in embryos due to effects of nitrogen, phosphorus and iron enrichment. Values are only given for treatments that had significant effect on embryo growth or phlorotannin concentrations (Tables $1 \& 3$ ). Directions of arrows indicate whether nutrient additions had positive ( $\uparrow$ ) or negative $(\downarrow)$ effect on growth of phlorotannin concentrations

\begin{tabular}{|c|c|c|c|c|c|c|}
\hline Enrichment & Weeks & Length & Width & $\begin{array}{l}\text { Rhizoid } \\
\text { length }\end{array}$ & $\begin{array}{c}\text { Surface } \\
\text { area }\end{array}$ & $\begin{array}{l}\text { Phlorotannin } \\
\text { concentration }\end{array}$ \\
\hline $\mathrm{N}$ & $\begin{array}{l}3 \\
6\end{array}$ & $\begin{array}{r}9.6 \% \uparrow \\
27.2 \% \uparrow\end{array}$ & $\begin{array}{l}3.6 \% \uparrow \\
9.9 \% \uparrow\end{array}$ & $\begin{array}{r}6.5 \% \downarrow \\
43.3 \% \uparrow\end{array}$ & $\begin{array}{l}18.4 \% \uparrow \\
36.4 \% \uparrow\end{array}$ & $\begin{array}{l}45.6 \% \downarrow \\
18.4 \% \downarrow\end{array}$ \\
\hline $\mathrm{P}$ & $\begin{array}{l}3 \\
6\end{array}$ & $\begin{array}{l}- \\
-\end{array}$ & $\begin{array}{l}- \\
-\end{array}$ & $\begin{array}{l}- \\
-\end{array}$ & $\begin{array}{l}- \\
-\end{array}$ & $\begin{array}{l}25.3 \% \downarrow \\
47.9 \% \downarrow\end{array}$ \\
\hline $\mathrm{Fe}$ & $\begin{array}{l}3 \\
6\end{array}$ & $\begin{array}{l}1.0 \% \uparrow \\
7.7 \% \downarrow\end{array}$ & $\begin{array}{l}1.2 \% \uparrow \\
9.0 \% \uparrow\end{array}$ & $\begin{array}{r}5.9 \% \downarrow \\
10.1 \% \downarrow\end{array}$ & $\begin{array}{l}4.9 \% \uparrow \\
4.3 \% \uparrow\end{array}$ & $\begin{array}{l}- \\
-\end{array}$ \\
\hline
\end{tabular}

Table 3. Fucus gardneri. Analysis of variance of angularly transformed phlorotannin concentrations of embryos grown in 8 different media enriched with nitrogen, phosphorus, and iron. Measurements of phlorotannin concentrations were made 27 and $48 \mathrm{~d}$ after cultures were started. Bold indicates treatments that had a significant effect on phlorotannin concentrations

\begin{tabular}{|c|c|c|c|c|c|}
\hline Source & df & SS & MS & $F$ & $\mathrm{p}$ \\
\hline $\mathbf{N}$ & 1 & 0.008210 & 0.008210 & 7.06 & 0.013 \\
\hline $\mathbf{P}$ & 1 & 0.011459 & 0.011459 & 9.86 & 0.004 \\
\hline $\mathrm{Fe}$ & 1 & 0.002101 & 0.002101 & 1.81 & 0.189 \\
\hline Time & 1 & 0.001955 & 0.001955 & 1.68 & 0.205 \\
\hline $\mathrm{N} \times \mathrm{P}$ & 1 & 0.002255 & 0.002255 & 1.94 & 0.174 \\
\hline $\mathrm{N} \times \mathrm{Fe}$ & 1 & 0.000090 & 0.000090 & 0.08 & 0.783 \\
\hline $\mathrm{N} \times$ Time & 1 & 0.000007 & 0.000007 & 0.01 & 0.937 \\
\hline $\mathbf{P} \times \mathbf{F e}$ & 1 & 0.009012 & 0.009012 & 7.75 & 0.009 \\
\hline $\mathrm{P} \times$ Time & 1 & 0.003149 & 0.003149 & 2.71 & 0.111 \\
\hline $\mathrm{Fe} \times$ Time & 1 & 0.000478 & 0.000478 & 0.41 & 0.526 \\
\hline $\mathrm{N} \times \mathrm{P} \times \mathrm{Fe}$ & 1 & 0.000057 & 0.000057 & 0.05 & 0.826 \\
\hline $\mathbf{N} \times \mathbf{P} \times$ Time & 1 & 0.005259 & 0.005259 & 4.53 & 0.042 \\
\hline $\mathrm{N} \times \mathrm{Fe} \times$ Time & 1 & 0.000002 & 0.000002 & 0.00 & 0.970 \\
\hline $\mathrm{P} \times \mathrm{Fe} \times$ Time & 1 & 0.002887 & 0.002887 & 2.48 & 0.126 \\
\hline $\mathrm{N} \times \mathrm{P} \times \mathrm{Fe} \times$ Time & 1 & 0.003546 & 0.003546 & 3.05 & 0.091 \\
\hline Error & 29 & 0.033705 & 0.001162 & & \\
\hline Total & 44 & 0.084170 & & & \\
\hline
\end{tabular}



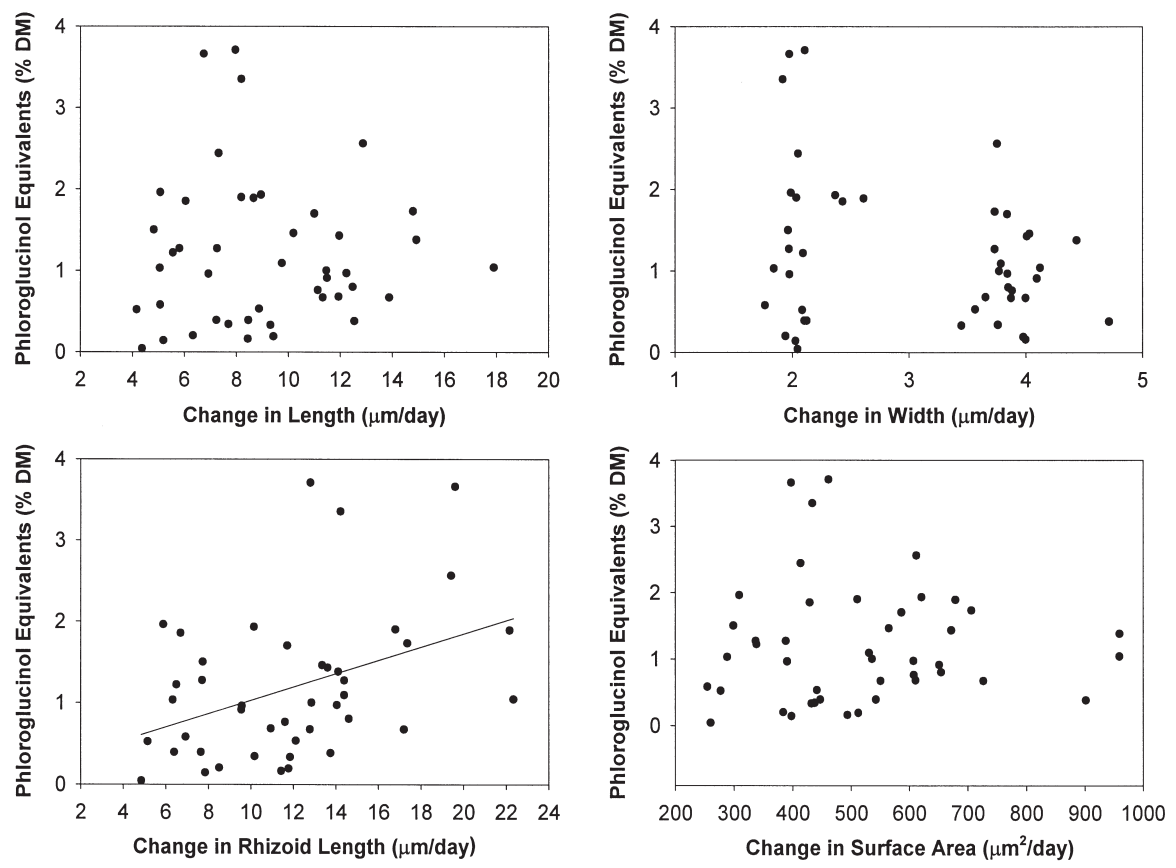

Fig. 2. Fucus gardneri. Phlorotannin size as a function of average daily changes in embryo length (linear regression: $p>0.05$ ), width (linear regression: $p>0.05$ ), rhizoid length (linear regression: $\mathrm{r}^{2}=15.1 \%, \mathrm{p}=0.005$ ), and surface area (linear regression: $p>0.05$ ) over $3 \mathrm{wk}$ period. Each data point represents results from a single culture dish measured at either 3 or $6 \mathrm{wk}$ from beginning of experiment. Lines are best-fit from simple linear regression. DM = dry mass
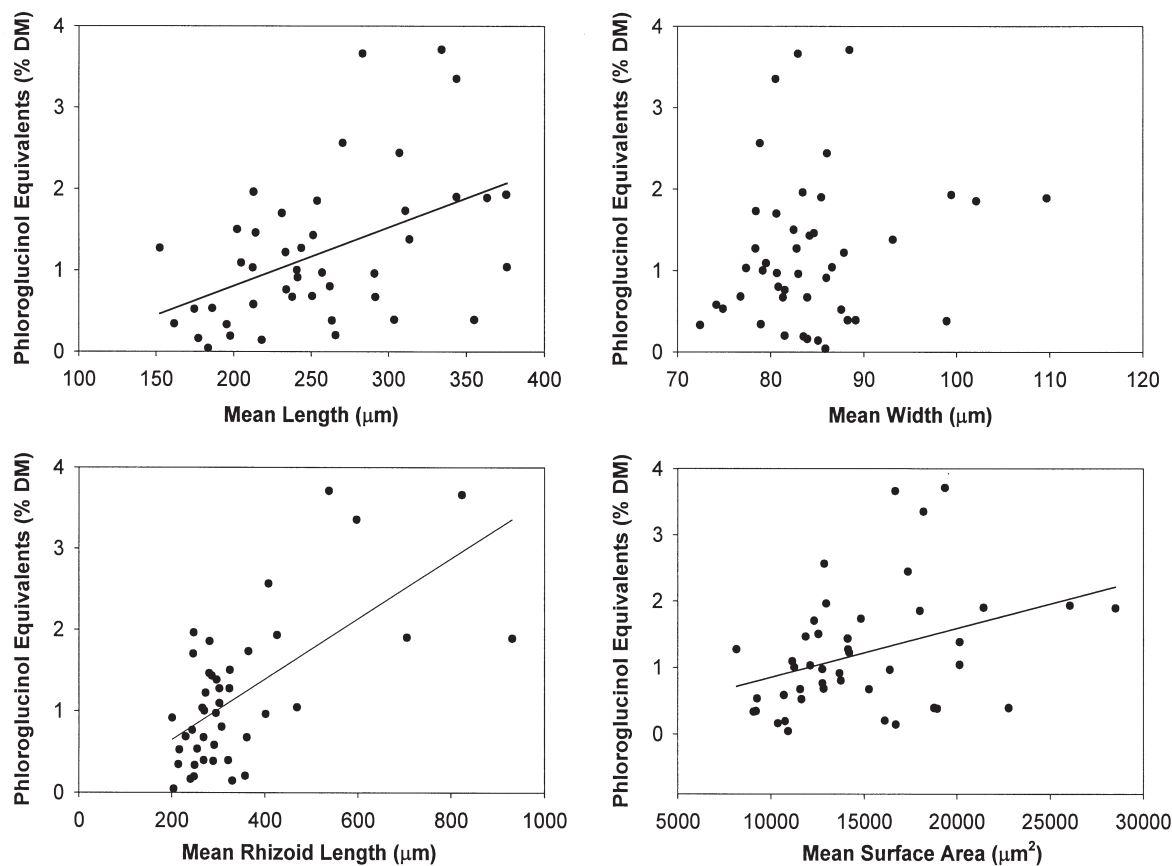

Fig. 3. Fucus gardneri. Phlorotannin size as a function of embryo length (linear regression: $\mathrm{r}^{2}=20.4, \mathrm{p}=0.001$ ), width (linear regression: $\mathrm{p}>0.05$ ), rhizoid length (linear regression: $\mathrm{r}^{2}=24.9, \mathrm{p}<0.001$ ), and surface area (linear regression: $\mathrm{r}^{2}=$ $11.3, \mathrm{p}=0.015)$. Each data point represents results from a single culture dish measured at either 3 or $6 \mathrm{wk}$ from beginning of experiment. Lines are best-fit from simple linear regression. DM = dry mass
The phlorotannin concentrations of the Fucus gardneri embryos in this study were low relative to concentrations in adult plants of the same species, which typically range from $\sim 5$ to $10 \%$ dry mass (DM) (Steinberg 1985, Van Alstyne 1988, 1989, Van Alstyne \& Paul 1990, Targett et al. 1992, Van Alstyne et al. 1999b,c). However, the concentrations in the cultures containing some of the larger individuals were as high as 3 to $4 \% \mathrm{DM}$, within the range of values seen in larger individuals from the field. Van Alstyne et al. (2001b) found that concentrations of phlorotannins in 1 to $2 \mathrm{~cm}$-long juvenile F. gardneri were significantly higher than concentrations in adults, and concentrations in 1 to $2 \mathrm{~cm}$-long juveniles decreased as the plants elongated.

The lower concentrations of phlorotannins in laboratory-cultured embryos suggests 2 possibilities. The first is that embryos allocate fewer resources to phlorotannin production than larger juveniles because survival at this stage is enhanced if these resources are used for growth. If phlorotannins function as an antiherbivore defense, they are likely to work by being distasteful during an initial attack by a grazer, and reducing subsequent attacks. Most temperate intertidal herbivores are not visual feeders, and therefore have to consume a portion of an alga to learn if it is distasteful. For example, littorinid snails will climb on damaged and undamaged Fucus gardneri at the same rate, but will leave the damaged F. gardneri that has higher phlorotannin concentrations faster than they will leave undamaged algae (Van Alstyne 1988). Embryos are unlikely to survive an initial attack by a grazer, whereas a larger juvenile might survive an initial attack although it might lose a significant proportion of its surface area. Consequently, the production of phlorotannins as chemical defenses by embryos would be of little or no benefit since they are unlikely 
to survive the first attack. Larger juveniles might benefit by having high concentrations of phlorotannins if they are effective at preventing subsequent tissue loss. The value of these defenses may decrease as plants get larger and the proportion of tissue lost during a single attack decreases.

An alternative explanation for the low phlorotannin concentrations of Fucus gardneri embryos in this study may be that phlorotannin production can be induced by environmental factors that are not present in laboratory-culture conditions. Phlorotannin concentrations are known to increase in response to physical damage (Van Alstyne 1988, 1989, Peckol et al. 1996, Hammerstrom et al. 1998) and increased UV-light levels (Pavia et al. 1997). Without these inducers present, phlorotannin concentrations may remain at lower concentrations.

Nutrient enrichment affected both embryo growth rates and phlorotannin concentrations. The results of the nitrogen-enrichment experiments supported some predictions of the carbon/nutrient balance hypothesis $(\mathrm{CNBH})$. The model predicted that an increase in the availability of a limiting nutrient should result in increases in growth and decreases in the production of carbon-based defensive compounds (Bryant et al. 1983). Of the 3 nutrients we supplemented in our growth experiments, only nitrogen produced overall increases in the size of Fucus gardneri embryos (Tables 1 \& 2). Iron enrichment affected embryo morphology, but not size, and phosphorus enrichment had no effects on embryo growth. Previous enrichment experiments involving Fucus spp. embryos have found similar responses. The addition of iron alone had no effect on $F$. edentatus embryos, but did increase growth in combination with nitrogen and phosphorus (McLachlan 1977); the highest growth rates of F. edentatus occurred when nitrogen, phosphorus, and iron were supplemented simultaneously. Culture experiments with adult Fucus spp. have also shown that growth is enhanced by nitrogen addition (Rosenberg et al. 1984, Creed et al. 1997).

Nitrogen enrichment resulted in decreases in embryo phlorotannin concentrations at both the 3 and 6 wk intervals. Our results are similar to the results Arnold et al. (1995) obtained with cultures of Lobophora variegata, despite large differences in the nitrogen concentrations of the baseline and enriched media. Our unenriched media had nitrogen concentrations of about $7 \mathrm{mg} \mathrm{l}^{-1}$, whereas Arnold et al.'s were $0.2 \mathrm{mg} \mathrm{l}^{-1}$. Concentrations in our enriched media were about $20 \mathrm{mg} \mathrm{l}^{-1}$, whereas the highest concentrations used by Arnold et al. were $5.2 \mathrm{mg} \mathrm{l}^{-1}$. Arnold et al. (1995) found direct positive correlations between nitrogen concentrations in the media and nitrogen concentrations in the algae and a negative correlation with phlorotannin concentrations.
Decreases in phlorotannin concentrations by combinations of nutrients that had no or negative effects on growth suggest that physiological stresses may be affecting phlorotannin concentrations. Phosphorus enrichment resulted in a large, 25 to $50 \%$, decrease in phlorotannin concentrations (Table 2), yet had no effect on growth (Table 1). Enrichment simultaneously with phosphorus and iron also resulted in sharp decreases in phlorotannin concentrations (Table 3, Fig. 1), as well as having negative effects on growth (Table 1). Van Alstyne et al. (2001a) suggest that changes in environmental factors such as nutrients can alter chemical defense concentrations in 3 ways: (1) they can provide cues for plants to alter concentrations of secondary metabolites to concentrations more appropriate for the environment at that time and place, such as the production of inducible defenses (Karban \& Baldwin 1997, Tollrian \& Harvell 1999), (2) they can alter the amounts of materials and energy available for defense production and how those resources are allocated to growth, reproduction and defense (Bryant et al. 1983, Coley et al. 1985, Herms \& Mattson 1992, Tuomi 1992), and (3) they can stress plants, resulting in an overall lowered physiological condition and lowered chemical defense concentrations (Renaud et al. 1990, Cronin \& Hay 1999a,b).

The addition of iron and phosphorus may be physiologically stressing the plants, resulting in lowered growth rates and phlorotannin concentrations. Other environmental factors that have detrimental effects on algal health can reduce concentrations of chemical defenses and affect the palatability of algae to herbivores. For example, prolonged periods of desiccation are stressful to marine algae (Renaud et al. 1990, Cronin \& Hay 1999b). Sea urchins, Arbacia punctulata, significantly preferred to consume Padina gymnospora that had been desiccated for 30 to 90 min than undesiccated algae. When extracts of P. gymnospora were coated onto a preferred food, urchins preferentially consumed algae coated with extracts from desiccated algae over extracts from undesiccated algae. The results of Renaud et al.'s (1990) study indicate that stressed P. gymnospora undergo changes in their chemistry that affect urchin feeding; however, it was not determined whether these changes were in the chemical defenses produced by the algae. When Dictyota ciliolata was emersed for $1 \mathrm{~h}$, photosynthetic rates decreased by $47 \%$ and respiration rates increased by $40 \%$ relative to undesiccated plants (Cronin \& Hay 1996b). Desiccated plants were consumed at a faster rate by the sea urchin $A$. punctulata and the amphipod Ampithoe longimana. This was correlated with decreases in the secondary metabolites pachydictyol A, dictyol $\mathrm{B}$ acetate and dictyodial in desiccated algae. Similar tests of the effects of desiccation on herbivore resistance were conducted by Renaud et al. (1990) on the brown alga $P$. gymnospora. 
Ultraviolet radiation also reduces the production of chemical defenses in some seaweeds. Dictyota ciliolata exposed to UV radiation had significantly lower concentrations of dictyol B acetate and dictyodial; however, concentrations of pachydictyol A were not different. The algae also grew more poorly, suffered higher mortality levels, but was not preferentially consumed by the amphipod Ampithoe longimana relative to algae that had been shielded from UV light (Cronin \& Hay 1996b). These results contrast with the effects of UV light on Ascophyllum nodosum which increases phlorotannin concentrations in response to UV-light exposure (Pavia et al. 1997).

The reasons for the reduction in phlorotannin concentrations with phosphorus enrichment were not clear. Phosphorus enrichment did not appear to be stressing embryos in ways that affected growth rates (Table 1); however, it may have affected embryo health in ways not determined by embryo size measurements. Phosphorus is generally not considered to be a limiting nutrient to coastal seaweeds and the mechanism by which increases in phosphorus would decrease phlorotannin production are not known. The decreases in growth and phlorotannin concentrations resulting from the combined effects of iron and phosphorus are also difficult to explain. Phosphorus addition is known to have deleterious effects on adult Fucus virsoides in the presence of other metals such as manganese, cobalt, and zinc (Munda \& Veber 1996). Furthermore, phlorotannins have been shown to chelate metals, including iron (Ragan \& Glombitza 1986, Targett \& Arnold 1998).

The results of these experiments show that phlorotannin concentrations in Fucus gardneri embryos are determined by a complex interaction of several different factors. These include the ontogenetic stage of the algae and resource-allocation shifts and physiological stresses that result from the addition of different nutrients. Because these factors can act synergistically, this study illustrates the importance of manipulating multiple factors simultaneously when looking at the role of environmental changes on plant secondary-metabolite production.

Acknowledgements. We are grateful to NCASI for the use of their incubators. G. Muller-Parker and 3 anonymous reviewers made many helpful comments on the manuscript. This work was funded by an NSF grant, IBN 98-96012 to K.L.V.A.

\section{LITERATURE CITED}

Agrawal AA, Karban R (1999) Why induced defenses may be favored over constitutive strategies in plants. In: Karban R, Baldwin IT (eds) Induced responses to herbivory. University of Chicago Press, Chicago, p 45-61
Arnold TM, Tanner CE, Hatch WI (1995) Phenotypic variation in polyphenolic content of the tropical brown alga Lobophora variegata as a function of nitrogen availability. Mar Ecol Prog Ser 123:177-183

Bazzaz FA, Chiariello NR, Coley PD, Pitelka LF (1987) Allocating resources to reproduction and defense. Bioscience 37:58-67

Bold HC, Wynne MJ (1985) Introduction to the algae. Prentice-Hall, Englewood Cliffs, NJ

Bryant JP, Chapin FS III, Klein DR (1983) Carbon/nutrient balance of boreal plants in relation to herbivory. Oikos 40: 357-368

Chapman ARO (1986) Population and community ecology of seaweeds. Adv Mar Biol 23:1-161

Chapman ARO (1990) Effects of grazing, canopy cover and substratum type on the abundances of common species of seaweeds inhabiting littoral fringe tidepools. Bot Mar 33: $319-326$

Coale $\mathrm{KH}$, and 18 others (1996) A massive phytoplankton bloom induced by an ecosystem-scale iron fertilization experiment in the equatorial Pacific Ocean. Nature 383: 495-501

Coley PD, Bryant JP, Chapin FS III (1985) Resource availability and plant antiherbivore defense. Science 230:895-899

Creed JC, Norton TA, Kain JM (1997) Intraspecific competition in Fucus serratus germlings: the interaction of light, nutrients and density. J Exp Mar Biol Ecol 212:211-223

Cronin G, Hay ME (1996a) Effect of light and nutrient availability on the growth, secondary chemistry, and resistance to herbivory of two brown seaweeds. Oikos 77:93-106

Cronin G, Hay ME (1996b) Susceptibility to herbivores depends on recent history of both the plant and animal. Ecology 77:1531-1543

Dean TA, Jacobsen FR, Thies K, Lagos SL (1988) Differential effects of grazing by white sea urchins on recruitment of brown algae. Mar Ecol Prog Ser 48:99-102

Delgado O, LaPointe BE (1994) Nutrient-limited productivity of calcareous versus fleshy macroalgae in a eutrophic, carbonate-rich tropical marine environment. Coral Reefs 13: 151-159

Denton A, Chapman ARO, Markham J (1990) Size-specific concentrations of phlorotannins (anti-herbivore compounds) in three species of Fucus. Mar Ecol Prog Ser 65:103-104

Downing JA, Osenberg CW, Sarnelle O (1999) Meta-analysis of marine nutrient-enrichment experiments: variation in the magnitude of nutrient limitation. Ecology 80: $1157-1167$

Fujita RM, Wheeler PA, Edwards RL (1989) Assessment of macroalgal nitrogen limitation in a seasonal upwelling region. Mar Ecol Prog Ser 53:293-303

Geiselman JA, McConnell OJ (1981) Polyphenols in brown algae Fucus vesiculosus and Ascophyllum nodosum: chemical defenses against the marine herbivorous snail, Littorina littorea. J Chem Ecol 7:1115-1133

Gunnill FC (1986) Demography of Cystoseira osmundacea and Halidrys dioica (Phaeophyta, Cystoseraceae) at La Jolla, California, USA. Bot Mar 29:137-146

Hammerstrom K, Dethier MN, Duggins DO (1998) Rapid phlorotannin induction and relaxation in five Washington kelps. Mar Ecol Prog Ser 165:293-305

Harris LG, Ebeling AW, Laur DR, Rowley RJ (1984) Community recovery after storm damage: a case of facilitation in primary succession. Science 224:1336-1338

Hawkins SJ (1981) The influence of Patella grazing on the fucoid barnacle mosaic on moderately exposed rocky shores. Kiel Meeresforsch (Sonderh) 5:537-543

Hawkins SJ (1983) Interactions of Patella and macroalgae 
with settling Semibalanus balanoides (L.). J Exp Mar Biol Ecol 71:55-72

Hawkins SJ, Hartnoll RG (1983) Grazing of intertidal algae by marine invertebrates. Oceanogr Mar Biol Annu Rev 21: 195-282

Herms DA, Mattson WJ (1992) The dilemma of plants: to grow or defend. Q Rev Biol 67:283-335

Ilvessalo H, Tuomi J (1989) Nutrient availability and accumulation of phenolic compounds in the brown alga Fucus vesiculosus. Mar Biol 101:115-119

Johnson LE, Brawley SH (1998) Dispersal and recruitment of a canopy-forming intertidal alga: the relative roles of propagule availability and post-settlement processes. Oecologia 117:517-526

Karban R, Baldwin IT (1997) Induced responses to herbivory. University of Chicago Press, Chicago

Keser M, Larson BR (1984) Colonization and growth dynamics of three species of Fucus. Mar Ecol Prog Ser 15:125-134

LaPointe BE (1995) A comparison of nutrient-limited productivity in Sargassum natans from neritic vs. oceanic waters of the western North Atlantic Ocean. Limnol Oceanogr 40: 625-633

LaPointe BE (1997) Nutrient thresholds for bottom-up control of macroalgal blooms on coral reefs in Jamaica and southeast Florida. Limnol Oceanogr 42:1119-1131

Larned ST (1998) Nitrogen- versus phosphorus-limited growth and sources of nutrients for coral reef macroalgae. Mar Biol 132:409-421

Lubchenco J (1983) Littorina and Fucus: effects of herbivores, substrate heterogeneity, and pant escapes during succession. Ecology 64:1116-1123

Martin JH, Fitzwater SE (1988) Iron deficiency limits phytoplankton growth in the northeast Pacific subarctic. Nature 331:341-343

Martin JH, and 43 others (1994) Testing the iron hypothesis in ecosystems of the equatorial Pacific Ocean. Nature 371: $123-129$

Martinez EA, Santelices B (1998) Selective mortality on haploid and diploid microscopic stages of Lessonia nigrescens Bory (Phaeophyta, Laminariales). J Exp Mar Biol Ecol 229: 219-239

McLachlan J (1973) Growth media-marine. In: Stein JR (ed) Handbook of phycological methods. Culture methods and growth measurements. Cambridge University Press, Cambridge, p 25-51

McLachlan J (1977) Effects of nutrients on growth and development of embryos of Fucus edentatus Pyl. (Phaeophyceae, Fucales). Phycologia 16:329-338

Munda IM, Veber M (1996) Simultaneous effects of trace metals and excess nutrients on the Adriatic seaweed Fucus virsoides (Don.) J. Ag. (Phaeophyceae, Fucales). Bot Mar 39:297-309

Nielsen KJ (1998) Bottom-up and top-down forces in tidepools: the influence of nutrients, herbivores and wave exposure on community structure. PhD dissertation, Oregon State University, Corvallis

Paul VJ, Van Alstyne KL (1988) Chemical defense and chemical variation in some tropical Pacific species of Halimeda (Halimedaceae; Chlorophyta). Coral Reefs 6:263-269

Pavia H, Cervin G, Lindgren A, Aberg P (1997) Effects of UV$B$ radiation and simulated herbivory on phlorotannins in the brown alga Ascophyllum nodosum. Mar Ecol Prog Ser 157:139-146

Pavia H, Toth G, Åberg P (1999) Trade-offs between phlorotannin production and annual growth in natural populations of the brown seaweed Ascophyllum nodosum. J Ecol $7: 761-771$
Pearson GA, Serrao EA, Brawley SH (1998) Control of gamete release in fucoid algae: sensing hydrodynamic conditions via carbon acquisition. Ecology 79:1725-1739

Peckol P, Krane, JM, Yates JL (1996) Interactive effects of inducible defense and resource availability on phlorotannins in the North Atlantic brown alga Fucus vesiculosus. Mar Ecol Prog Ser 38:209-217

Pedersen MF, Borum J (1996) Nutrient control of algal growth in estuarine waters. Nutrient limitation and the importance of nitrogen requirements and nitrogen storage among phytoplankton and species of macroalgae. Mar Ecol Prog Ser 142:261-272

Pedersen MF, Borum J (1997) Nutrient control of estuarine macroalgae: growth strategy and the balance between nitrogen requirements and uptake. Mar Ecol Prog Ser 161: 155-163

Puglisi MP, Paul VJ (1997) Intraspecific variation in the red alga Portieria hornemannii: monoterpene concentrations are not influenced by nitrogen or phosphorus enrichment. Mar Biol 128:161-170

Ragan MA, Glombitza K (1986) Phlorotannins, brown algal polyphenols. In: Round FE, Chapman DJ (eds) Progress in phycological research, Vol 4. Biopress, Bristol, p 129-241

Renaud PE, Hay ME, Schmitt TM (1990) Interactions of plant stress and herbivory: intraspecific variation in the susceptibility of a palatable versus an unpalatable seaweed to sea urchin grazing. Oecologia 82:217-226

Rosenberg G, Probyn TA, Mann KH (1984) Nutrient uptake and growth kinetics in brown seaweeds: response to continuous and single additions of ammonium. J Exp Mar Biol Ecol 80:125-146

Santelices B (1990) Patterns of reproduction and recruitment in seaweeds. Oceanogr Mar Biol Annu Rev 28:177-276

Short FE, Davis MW, Gibson RA, Zimmermann CF (1985) Evidence for phosphorus limitation in carbonate sediments of the seagrass Syringodium filiforme. Coast Shelf Sci 20: 419-430

Steinberg PD (1985) Feeding preferences of Tegula funebralis and chemical defenses of marine brown algae. Ecol Monogr 55:333-349

Steinberg PD (1988) The effects of quantitative and qualitative variation in phenolic compounds on feeding in three species of marine invertebrate herbivores. J Exp Mar Biol Ecol 120:221-237

Steinberg PD, Van Altena I (1992) Tolerance of marine invertebrate herbivores to brown algal phlorotannins in temperate Australia. Ecolog Monogr 62:189-222

Steinberg PD, Estes JA, Winter FC (1995) Evolutionary consequences of food chain length in kelp forest communities. Proc Natl Acad Sci USA 92:8145-8148

Stimson J, Larned S, McDermid K (1996) Seasonal growth of the coral reef macroalga Dictyosphaeria cavernosa (Forskaal) Borgesen and the effects of nutrient availability, temperature and herbivory on growth rate. J Exp Mar Biol Ecol 196:53-77

Suzuki Y, Kuma K, Matsunaga K (1995) Bioavailable iron species in seawater measured by macroalga (Laminaria japonica) uptake. Mar Biol 123:173-178

Targett NM, Arnold TM (1998) Predicting the effects of brown algal phlorotannins on marine herbivores in tropical and temperate oceans. J Phycol 34:195-205

Targett NM, Coen LD, Boettcher AA, Tanner CE (1992) Biogeographic comparisons of marine algal phenolics: evidence against a latitudinal trend. Oecologia 89:464-470

Tollrian R, Harvell CD (1999) The ecology and evolution of inducible defenses. Princeton University Press, Princeton 
Tuomi J (1992) Toward integration of plant defence theories. Trends Ecol Evol 7:365-367

Vadas RL Sr, Johnson S, Norton TA (1992) Recruitment and mortality of early post-settlement stages of benthic algae. Br Phycol J 27:331-351

Van Alstyne KL (1988) Herbivore grazing increases polyphenolic defenses in the intertidal brown alga Fucus distichus. Ecology 69:655-663

Van Alstyne KL (1989) Adventitious branching as an herbivore induced defense in the intertidal brown alga Fucus distichus. Mar Ecol Prog Ser 56:169-176

Van Alstyne KL (1995) A comparison of three methods for quantifying brown algal polyphenolic compounds. J Chem Ecol 21:45-58

Van Alstyne KL, Paul VJ (1990) The biogeography of polyphenolic compounds in marine macroalgae: temperate brown algal defenses deter feeding by tropical herbivorous fishes. Oecologia 84:158-163

Van Alstyne KL Ehlig JM, Whitman SL (1999a) Feeding preferences for juvenile and adult algae depend on algal stage and herbivore species. Mar Ecol Prog Ser 180:179-185

Van Alstyne KL, McCarthy JJ III, Hustead CL, Duggins DO (1999b) Geographic variation in polyphenolic levels of northeastern Pacific kelps and rockweeds. Mar Biol 133: 371-379

Van Alstyne KL, McCarthy JJ III, Hustead CL, Kearns LJ (1999c) Phlorotannin allocation among tissues of north-

Editorial responsibility: Charles Birkeland (Contributing Editor), Mangilao, Guam eastern Pacific kelps and rockweeds. J Phycol 35:483-492

Van Alstyne KL, Dethier MN, Duggins DO (2001a) Spatial variation in algal chemical defenses. In: McClintock J, Baker W (eds) Marine chemical ecology (in press)

Van Alstyne, KL, Whitman SL, Ehlig JM (2001b) Ontogenetic shifts in phlorotannin production, nutritional quality, and susceptibility to herbivory in marine brown algae. Mar Biol (in press)

Watson DC, Norton TA (1987) The habitat and feeding preferences of Littorina obtusata (L.) and L. mariae Sacchi et Rastelli. J Exp Mar Biol Ecol 112:61-72

Wheeler PA, Björnsäter BR (1992) Seasonal fluctuations in tissue nitrogen, phosphorus and N:P for five macroalgal species common to the Pacific northwest coast. J Phycol 28: $1-6$

Winter FC, Estes JA (1992) Experimental evidence for the effects of polyphenolic compounds from Dictyoneurum californicum Ruprecht (Phaeophyta: Laminariales) on feeding rate and growth in the red abalone Haliotus rufescens Swainson. J Exp Mar Biol Ecol 155:263-277

Wootton JT, Power ME, Paine RT, Pfister CA (1996) Effects of productivity, competitors, and El Niño events on food chain patterns in a rocky intertidal community. Proc Natl Acad Sci USA 93:13855-13858

Yates JL, Peckol P (1993) Effects of nutrient availability and herbivory on polyphenolics in the seaweed Fucus vesiculosus. Ecology 74:1757-1766

Submitted: December 15, 1999; Accepted: May 11, 2000

Proofs received from author(s): September 26, 2000 